\title{
Emerging SARS-CoV-2 variants of concern and potential intervention approaches
}

\author{
Jasmin Khateeb ${ }^{1,2}$, Yuchong $\mathrm{Li}^{1,3}$ and Haibo Zhang ${ }^{1,3,4^{*}}$ (]
}

\begin{abstract}
The major variant of concerns (VOCs) have shared mutations in severe acute respiratory syndrome coronavirus 2 (SARS-CoV-2) spike proteins, mostly on the S1 unit and resulted in higher transmissibility rate and affect viral virulence and clinical outcome. The spike protein mutations and other non-structural protein mutations in the VOCs may lead to escape approved vaccinations in certain extend. We will discuss these VOC mutations and discuss the need for combination therapeutic strategies targeting viral cycle and immune host responses.
\end{abstract}

Keywords: Transmissibility, Viral virulence, B.1.1.7, B.1.351, P.1 B.1617.1

\section{Background}

The surge of new severe acute respiratory syndrome coronavirus 2 (SARS-CoV-2) variants of concern (VOC) poses a major threat on international public health as the rapid change of the SARS-CoV-2 genome may alter viral phenotypes such as virulence, transmissibility, and ability to evade host response giving rise to greater challenge to diagnostic and clinical management $[1,2]$. Yet, it is unclear whether the approved vaccines are effective against the VOCs. This article will summarize the main emerging VOCs and their potential epidemiological impact aiming at promoting development of drug therapy and effective vaccines and formulation of public health strategies.

\section{SARS-CoV-2 genome and mutations}

SARS-CoV-2 is a positive-sense single-stranded RNA virus whose genome is of a low stability thus is more prone for mutation accumulation, with approximately $9.8 \times 10^{-4}$ substitutions/site yearly [3-7]. The architecture of SARS-CoV-2 is made of two groups of proteins:

\footnotetext{
*Correspondence: haibo.zhang@unityhealth.to

1 Keenan Research Centre for Biomedical Science, St. Michael's Hospital,

Unity Health Toronto, Room 619, LKSKI, 30 Bond Street, Toronto, ON M5B1W8, Canada

Full list of author information is available at the end of the article
}

structural proteins (SP) and non-structural proteins (NSP). SPs are encoded by 4 genes, including E (envelop), $\mathrm{M}$ (membrane), $\mathrm{S}$ (spike) and $\mathrm{N}$ (nucleocapsid) genes [8]. NSPs are mostly enzymes or functional proteins that play a role in viral replication and methylation and may induce host responses to infection. These genes are encoded in several groups, namely ORF1a (NSP111), ORF1b (NSP12-16), ORF3a, ORF6, ORF7a, ORF7b, ORF8 and ORF10.

A variant can be as simply as a virus bearing a deviant mutation or complicated combinations of deviations leading to significant phenotypical alteration from original genome. Although by the beginning of May 2021, there has been reported more than 1.4 million sequences and among them 3913 major representative variants genomes that have been identified and included in the global SARS-CoV-2 sequence database operated by Global Initiative on Sharing Avian Influenza Data (GISAID) [9], not all genetic mutations lead to variation in major proteins and/or alter virus infectivity. The spike gene mutations account for most of the clinically influential VOCs while the ORF1a frame of the genome serves as a key region for NSP mutations.

We will focus our discussion here on the VOCs that have major global health impacts since the $4^{\text {th }}$ quarter of the year 2020, including Alpha variant (B.1.1.7), Beta

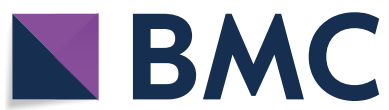

(c) The Author(s) 2021. Open Access This article is licensed under a Creative Commons Attribution 4.0 International License, which permits use, sharing, adaptation, distribution and reproduction in any medium or format, as long as you give appropriate credit to the original author(s) and the source, provide a link to the Creative Commons licence, and indicate if changes were made. The images or other third party material in this article are included in the article's Creative Commons licence, unless indicated otherwise in a credit line to the material. If material is not included in the article's Creative Commons licence and your intended use is not permitted by statutory regulation or exceeds the permitted use, you will need to obtain permission directly from the copyright holder. To view a copy of this licence, visit http://creativecommons.org/licenses/by/4.0/. The Creative Commons Public Domain Dedication waiver (http://creativeco mmons.org/publicdomain/zero/1.0/) applies to the data made available in this article, unless otherwise stated in a credit line to the data. 
(B.1.351), Gamma (P.1) and Kappa and Delta (B.1.617.1 and B.1.617.2) (Table 1).

\section{Spike mutations}

Spike protein mediates the virus attachment to human cell surface angiotensin converting enzyme 2 (ACE2) receptor, thus facilitating viral entry during infection [10-12]. It is split into two subunits, S1 and S2. The S1 unit possess the receptor-binding domain (RBD) which can directly bind to ACE2 receptor and is also the dominant target of neutralizing antibodies (Ab) against SARS$\mathrm{CoV}-2$. S1 is thus considered a hotspot for mutations that may have high clinical relevance in terms of virulence, transmissibility, and host immune evasion [13-16] (Table 2).

The Alpha variant has an N501Y mutation: at the 501 residue, $\mathrm{N}$ asparagine has been replaced with $\mathrm{Y}$ tyrosine, as well as $\mathrm{K} 417 \mathrm{~N}-$ lysine $\mathrm{K}$ replaced with asparagine $\mathrm{N}$ [9]. An emerging variant derived from B.1.1.7 also carries E484K mutation-glutamic acid E replaced with lysine $\mathrm{K}$ [9]. Both Beta and Gamma variants have more substitutions other than N501Y [9]. The Beta variant has E484K, while the Gamma variant has the E484K and the K417T mutations [9]. The latest major variants, Delta and Kappa, sharing two mutations E484Q (glutamic acid E substituted by glutamine Q) and L452R (leucine L altered by arginine R) were identified in India's second COVID19 wave. Other than the two mutations above, Delta also harbours a unique mutation, T478K (threonine $\mathrm{T}$ replaced by lysine K) [9].

The S1 mutations significantly increases the binding affinity to ACE2 while showing lower affinity to neutralizing antibodies [17-21], suggesting a possible explanation for their occurring higher transmissibility and virulence [22, 23].

Another mutation at non-RBD sites, named D614G, is the most spreading mutation carried by over $99 \%$ of prevalent variants since early 2020 [23, 24]. Such mutation does not change the binding affinity to ACE2 or neutralizing Abs for the virion, yet it may increase spike density by preserving the integrity of spike and avoiding S1 shedding [25]. With more functional spikes available, D614G variants are armed with increased infectivity and hence increased replication in vitro while earlier transmission in vivo $[23,25,26]$. Recently, increasing deletions are observed in the neutralizing Ab-recognizing domain, namely recurrent deletion regions (RDRs), in the N-terminus of S1 subunit [27]. Deletions in RDRs wipe out the epitopes, and eventually aiding the virus evading host's immune supervision and potentially defecting certain

Table 1 Molecular and clinical characteristics of SARS-CoV-2 variants of concern

\begin{tabular}{|c|c|c|c|c|c|}
\hline Variant of concern & & $\begin{array}{l}\text { Alpha } \\
\text { B.1.1.7 }\end{array}$ & $\begin{array}{l}\text { Beta } \\
\text { B.1.351 }\end{array}$ & $\begin{array}{l}\text { Gamma } \\
\text { P.1 }\end{array}$ & $\begin{array}{l}\text { Delta and Kappa* } \\
\text { B.1.617.2 } \\
\text { B.1.617.1 }\end{array}$ \\
\hline \multirow[t]{3}{*}{ Epidemiology } & First Identified & $\begin{array}{l}\text { September. } \\
\text { 2020, } \\
\text { UK }\end{array}$ & $\begin{array}{l}\text { October. 2020, } \\
\text { South Africa }\end{array}$ & $\begin{array}{l}\text { December. 2020, } \\
\text { Japan \& Brazil }\end{array}$ & $\begin{array}{l}\text { December. 2020, } \\
\text { India }\end{array}$ \\
\hline & Global frequency** & $48 \%$ & $7 \%$ & $7 \%$ & $14 \%$ \\
\hline & Major geographic distribution & Worldwide & South Africa & South America & Asia \\
\hline \multirow[t]{2}{*}{ Predominant mutations } & Spike RBD mutations & N501Y & K417N, E484K, N501Y & K417T, E484K, N501Y & $\begin{array}{l}\text { L452R, E484Q, } \\
\text { T478K (Delta) }\end{array}$ \\
\hline & Spike non- RBD mutations & D614G, P681H & D614G & D614G & D614G, P681R \\
\hline \multirow[t]{4}{*}{ Clinical considerations *** } & Transmissibility & $\uparrow * * * *$ & $\uparrow ?$ & $\uparrow ?$ & $\uparrow ?$ \\
\hline & Virulence & $\uparrow ?$ & $\uparrow ?$ & $\uparrow ?$ & $\uparrow ?$ \\
\hline & Host Immune response & $\downarrow$ & $\downarrow$ & $\downarrow ?$ & $\downarrow ?$ \\
\hline & Diagnostic tools & $\leftrightarrow$ & $\leftrightarrow$ & $\leftrightarrow$ & $\leftrightarrow$ \\
\hline \multirow[t]{7}{*}{ Therapeutic considerations*** } & Vaccinations' effectivity & & & & \\
\hline & mRNA- based & $\leftrightarrow$ & $\downarrow$ & $\leftrightarrow$ & $?$ \\
\hline & Adenovirus-based & $\downarrow$ & $\downarrow$ & $\downarrow$ & $?$ \\
\hline & $\begin{array}{l}\text { Recombinant protein-based vac- } \\
\text { cines }\end{array}$ & $\downarrow$ & $\downarrow \downarrow$ & $?$ & $?$ \\
\hline & Inactivated virus-based & $\leftrightarrow$ & $\downarrow$ & $\leftrightarrow$ & $?$ \\
\hline & \multicolumn{5}{|c|}{ Potential therapeutic strategies } \\
\hline & \multicolumn{5}{|c|}{$\begin{array}{l}\text { S1 RBD targeted therapeutics: Soluble human recombinant ACE2, anti-RBD nanobodies } \\
\text { Endosomal formation interruption: TMPRSS2 inhibitors (e.g., Camostat), ADAM17 inhibitors, Viral replication-oriented } \\
\text { therapies: RdRp inhibitors (e.g. Remdesivir, GS-441524), Cas13d-based PAC-MAN }\end{array}$} \\
\hline
\end{tabular}

*Delta and Kappa are derived from the emerging lineage B.1.617; ${ }^{* *}$ Last updated June $6{ }^{\text {th }}, 2021 ;{ }^{* * *}$ All data is suggestive according to in vitro experiments unless mentioned otherwise; ${ }^{* * *}$ Clinical data showed higher transmissibility rate of $35-45 \%$ especially in younger group ages and children. 
Table 2 Major spike mutations

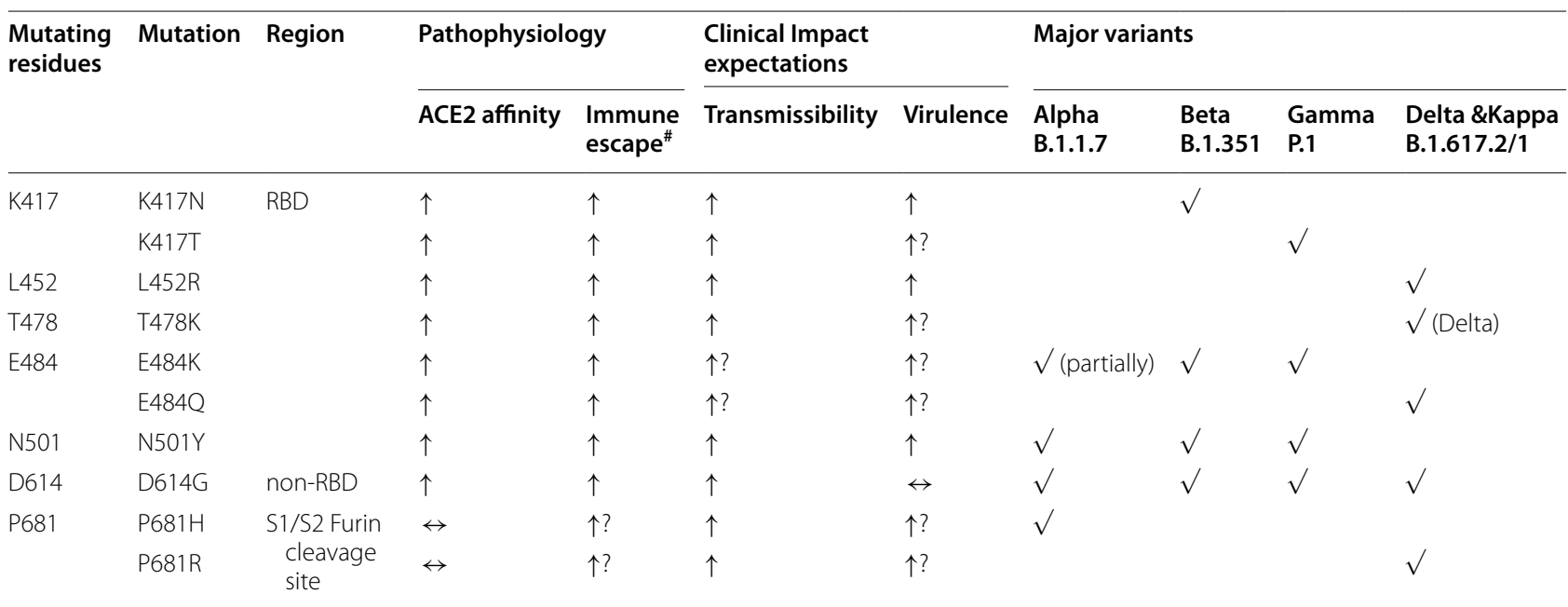

\# Both host and vaccine-induced immunity. Abbreviations: RBD, receptor binding domain

neutralizing Abs or vaccines. A majority of Alpha derived variants ( $\triangle$ RDR1, S: $\triangle$ HV 69-70, \& $\Delta$ RDR2, S: $\Delta$ Y144), Beta derived variants ( $\triangle$ RDR4, S: $\triangle$ LAL 242-244) and B.1.36 ( $\triangle \mathrm{RDR} 3, \mathrm{~S}: \Delta \mathrm{I} 210)$ carry this kind of mutation [27].

\section{NSP mutations}

Two mutation hot-spots, NSP1 of ORF1a/ORF1ab, and ORF8, have been found related to the virulence and transmissibility. NSP1 is a key protein to antagonize type I interferon induction in the host and benefit the replication of the virus itself $[28,29]$. ORF8 is known as an immune-evasive protein that downregulates major histocompatibility complex class I (MHC-I) in host cells [30, 31]. Recently, the Alpha variant, identified from a single immunocompromised individual, was shown to contains a premature stop codon at position 27 of ORF8[32].

Variants with partial deletion of NSP1 and ORF8 have been identified (e.g., the NSP1: $\triangle 500-532$ variant in Sichuan, China, and the ORF8: $\Delta 382$ variant in Singapore) $[29,31]$. Despite that truncated NSP1 and ORF8 both contribute to milder infections [29-31] and account for less than $5 \%$ of infections worldwide, they have become the major variants in Africa since late 2020[9].

\section{Potential clinical impacts of SARS-CoV-2 VOCs Increased transmissibility and viral virulence}

It was shown that S-protein mutation D614G may impact SARS-CoV-2 transmissibility rate due to higher affinity for olfactory epithelium and it was shown to have higher transmissibility in animal models [33, 34]. It was also shown that it has a higher virion stability and was shown to be more resistant to proteolytic cleave as well as higher viral titer in upper airways $[35,36]$ suggesting that it may potentially affect virus transmissibility and virulence. Yet, it showed increased susceptibility for neutralizing antibodies and no difference in clinical severity nor hospitalization outcomes and mortality was observed [37, 38].

Evidence suggest that the VOCs Alpha and Beta increased transmissibility rate at $50 \%$ especially in younger group ages and children [39, 40]. Alpha variant was shown to increase hospitalizations and mortality that may be attributed to their escape from neutralizing Abs due to their RBD mutations [41].

The Epsilon variant (B.1.427/B.1.429, California variants) increased transmissibility up to $24 \%$ with higher viral shedding, which is attributed to the of L452R spike mutation that was shown to stabilize spike-ACE2 receptor interaction [42, 43].

Although it is also suggested that other variants such as Gamma, Epsilon variants and recent Iota variants (B.1526, New York variant) may also have increased virulence due to spike mutations that increase affinity to ACE2, there is still no data available regarding viral virulence.

\section{Decreased diagnostic sensitivity}

The new VOCs can reduce the detection sensitivity of RT-PCR based diagnostic tools especially when mutations occur in locations where probes and primers may bind [44]. Reports suggest that $79 \%$ of the primer binding sites used in the RT-PCR assay are already mutated in at least one genome with the highest significance of the GGG $\rightarrow$ AAC substitution [45]. Recent analysis which mapped primers or probes binding sites showed a cumulative variants frequency of $\geq 1 \%$ in the global 
SARS-CoV-2 genomes [46]. The Alpha lineage was shown to have higher false-negative results when using specific commercial kits directed to the spike (S) gene but not when using standard protocols such as Berlin-Cherite protocol since it does not involve the $\mathrm{S}$ protein-encoding gene as target [47]. Another concern is a variant detected in France of a $S$ deletion $(\Delta \mathrm{H} 69-\mathrm{V} 70)$ which has shown to be associated with S-gene target gene detection failure in three-target RT-PCR [48]. Several reports have targeted mutations in different open reading frames (ORFs) especially ORF8 position which was found in some isolates from Mexico, Belize and Guatemala as potentially leading to epitope loss and reduced sensitivity for serological testing [49-51].

On the other hand, other studies showed that although mismatches in the primer/probes binding regions of SARS-CoV-2 diagnostic assays can be detected in different SARS-CoV-2 variants, they were tolerated and did not result in reduced assay performance and false-negative results [52, 53]. Moreover, according to bioinformatic analysis performed, the known variability occurring in the SARS-CoV-2 population have minimal or no effect on the sensitivity existing diagnostic tools for viral detection $[54,55]$.

Still, the continuous emergence of SARS-CoV-2 variants and possible mismatches highlight the importance of global molecular surveillance and designing diagnostic strategies such as combining diagnostic methods during future outbreaks or perform assays that target two or more positions in highly conserved regions of the viral genome to promote higher specificity and sensitivity results as well as developing highly specific diagnostic tools using CRISPR $[56,57]$.

\section{Potential influence on vaccination}

Currently, all vaccines are based on introducing spike protein, which is the major superficial virulence of SARS$\mathrm{CoV}-2$, using the reference genome isolates early in the pandemic. As there is no sufficient evidence to support the effect of vaccines against Delta and Kappa variants, we'll focus on the Alpha, Beta and Kappa variants.

\section{mRNA Vaccines}

Two major mRNA-based anti-SARS-CoV-2 vaccines have been approved: BNT162b2 (Pfizer-BioNTech) and mRNA-1273 (Moderna). Studies suggest that BNT162b2 vaccines were able to stimulate the recipients to generate capable antibodies to neutralize Alpha and Gamma variants yet being significantly less protective against Beta variant $[41,58,59]$ mRNA-1273 was shown to enhance sufficient neutralizing ability against Alpha variant yet lower reciprocal titer against Beta variant $[41,60,61]$.

\section{Adenovirus-based vaccines}

There are 4 adenovirus-based vaccines that have been authorized for general or emergency use. Among of which, Ad26.COV2.S is a recombinant, replicationincompetent adenovirus serotype 26 (Ad26) vector encoding a full-length and stabilized SARS-CoV-2 spike protein (Janssen) was shown to have reduced efficacies to Beta variant (64\%) and Gamma dominant Latin America variant (61\%), compared to the U.S. (72\%) where Alpha is the dominant strain [62]. ChAdOx1 nCoV-19 (Oxford) is a chimpanzee adenovirus-vectored vaccine expressing the SARS-CoV-2 spike protein. Recent studies revealed that the efficacy of ChAdOx $1 \mathrm{nCoV}-19$ was $74.6 \%$ against Alpha but as low as $10.4 \%$ against Beta [63, 64]. GamCOVID-Vac (Ad26 and Ad5) is also claimed protective to the global VOCs, yet the clinical trial result has not yet been publicized [65]. An ongoing clinical trial on the combination of ChAdOx1 nCoV-19 and Gam-COVIDVac (Russia), which is a heterologous COVID-19 vaccine consisting of two components, a recombinant adenovirus type 26 (rAd26) vector and a recombinant adenovirus type 5 (rAd5) vector, both carrying the gene for SARS$\mathrm{CoV}-2$ spike glycoprotein. There is no data regarding its efficacy on VOCs [66].

\section{Subunit vaccines}

NVX-CoV2373 (Novavax) contains a full-length, prefusion spike protein, and shows an $86.3 \%$ efficacy against Alpha, yet $48.6 \%$ against Beta [67]. However, none of the recombinant protein-based vaccines have yet to be approved for general use.

\section{Inactivated virus-based vaccines}

Three inactivated virus- based vaccines have been approved so far and have been widely used in China, India and Brazil. A recent in vitro study suggests that antisera elicited by BBIBP-CorV vaccine (Sinopharm) are able to neutralize the Beta variant in a differentially weaker level compared to the wildtype strain and the D614G variant [68]. A recent serological study has shown that BBV152 (Bharat Biotech International Limited) vaccinated human serum is able to neutralize the Alpha variant [69]. Preliminary data from a study conducted in Sao Paulo, Brazil indicate that the most widely vaccinated vaccine, CoronaVac (Sinovac Biotech), is effective against Gamma variant [70]. The same research facility claimed the vaccine also 'works well' against the Alpha and Gamma variants [71].

To conclude, it appears that Beta is most likely variant to affect the approved vaccines efficiency while Alpha and Gamma variants do not. These results suggest that a new vaccine might be required specifically to target Beta 
variant. Many strategies are currently under development to cope with Beta variant challenge such as booster vaccines [72].

\section{Potential therapeutics for VOCs S1 RBD targeted therapy}

Whether specifically targeting spike proteins using small peptide-based therapies or using single-domains neutralizing antibodies against any of those targets, these therapeutic strategies efficiency may be compromised by the emergence of SARS-CoV-2 variants especially those possessing spike proteins and RBD mutations that increase affinity to ACE2 such as Alpha, and Iota variant, by potentially escaping neutralizing antibodies and competing with those agents for the same binding targets [73-75]. In order to avoid antibody escape, strategies to combine different neutralizing antibody cocktail have been suggested as a therapeutic approach against the emerging variants [76]. Other treatments such as anti-RBD nanobodies isolated from llamas were shown to neutralize RBD variants suggesting they might be a promising tool against new SARS-CoV-2 VOCs as well $[77,78]$.

Different engineered variants of human recombinant soluble ACE2 (hrACE2), were reported to significantly inhibit SARS-CoV-2 infection in vitro and causing sustained viral entry blockade upon engagement of hrACE2 with the RBD in SARS-CoV-2 S protein with high affinity [79-81]. This is a potentially powerful treatment against SARS-CoV-2 VOCs as it can exploit the increase S-protein host receptor-binding affinity caused by S-mutations, toward increasing S-protein affinity to hrACE2. Moreover, no mutations that limit receptor-binding affinity were discovered as this will decrease affinity to native ACE2 receptor and may likely to attenuate virulence [82], suggesting that viral escape from hrACE is very unlikely.

\section{Interruption of endosomal formation}

Targeting endosomal formation of SARS-CoV-2 to block entry to host cells such as antimalarial drugs and macrolides, and us of drugs targeting host cell transmembrane protease serine 2 (TMPRSS2) such as Camostat [83-85] or A disintegrin and metalloprotease 17 (ADAM17) inhibitors [86].

\section{Interruption of SARS-CoV-2 VOC genome}

Promising antiviral drugs such as the FDA-approved Remdesivir and its metabolites, Ribaverin and Galidesivir have been shown to inhibit viral replication in vitro and in vivo studies due to their effect on inhibiting RNA dependent RNA polymerase (RdRp) [87, 88]. The discovery of RdRp hotspot mutations in SARS-CoV-2, found mostly in European strains may lead to drug-resistance of to RdRp inhibitors in a similar mechanism found in Influenza and Hepatitis C [89-91]. However, it has been shown currently that those variants have minimal impact for pre-existing resistance to Remdesivir.

Another potential approach is Prophylactic Antiviral CRISPR in Human Cells (PAC-MAN), which is a Cas13dbased strategy that target reserved regions such as nucleocapsid protein and RdRp in SARS-CoV-2 viral genome and may serve as pan-coronavirus strategy for any future coronaviruses and variant that may emerge [92].

\section{Conclusion}

Emerging VOCs have the potential to effect clinical and global health outcomes, emphasizing the necessity for genomically tailored therapeutic approach in the future therefore we suggest that a combination strategy targeting different components in viral cycle and immune host response may be critical but overlooked in the combat against SARS-CoV-2 VOCs.

\section{Abbreviations \\ Ab: Antibodies; ACE2: Angiotensin Converting Enzyme 2; ADAM17: A disintegrin and metalloprotease 17; E: Envelope; GISAID: Global Initiative on Sharing Avian Influenza Data; hrACE2: Human Recombinant Soluble Angioten- sin Converting Enzyme 2; M: Membrane; MHC-I: Major Histocompatibility Complex Class I; N: Nucleocapsid; NSP: Non-Structural Proteins; ORF: Open Reading Frames; PAC-MAN: Prophylactic Antiviral CRISPR in Human Cells; RBD: Receptor-Binding Domain; RDR: Recurrent Deletion Regions; RdRp: RNA dependent RNA polymerase; S: Spike; SARS-CoV-2: Severe Acute Respiratory Syndrome Coronavirus 2; SP: Structural Proteins; TMPRSS2: Transmembrane Protease Serine 2; VOC: Variant Of Concern.}

\section{Acknowledgements}

Not Applicable.

\section{Authors' contributions}

$J K$ and $Y L$ did the literature search and drafted the paper. JK, $Y L$ and $H Z$ revised the paper, tables and graphic abstract. The authors read and approved the final manuscript.

Funding

Not applicable.

Availability of data and materials

Not applicable.

\section{Declarations}

Ethics approval and consent to participate Not applicable.

Consent for publication

Not applicable.

Competing interests

The authors declare that they have no competing interests.

\section{Author details}

${ }^{1}$ Keenan Research Centre for Biomedical Science, St. Michael's Hospital, Unity Health Toronto, Room 619, LKSKI, 30 Bond Street, Toronto, ON M5B1W8,

Canada. ${ }^{2}$ Department of Internal Medicine D, Rambam Health Care Campus, Haifa, Israel. ${ }^{3}$ The State Key Laboratory of Respiratory Disease, Guangzhou 
Institute of Respiratory Disease, The First Affiliated Hospital of Guangzhou Medical University, Guangzhou, Guangdong, China. ${ }^{4}$ Departments of Anaesthesia and Physiology, Interdepartmental Division of Critical Care Medicine, University of Toronto, Toronto, ON, Canada.

Received: 8 June 2021 Accepted: 29 June 2021

Published online: 12 July 2021

\section{References}

1. COVID-19 daily epidemiology update - Canada.ca [Internet]. [cited 2021 May 8]. https://health-infobase.canada.ca/covid-19/epidemiologicalsummary-covid-19-cases.html

2. Berry I, Soucy JPR, Tuite A, Fisman D. Open access epidemiologic data and an interactive dashboard to monitor the COVID-19 outbreak in Canada. CMAJ. Canadian Medical Association; 2020. p. E420.

3. Duchene S, Featherstone L, Haritopoulou-Sinanidou M, Rambaut A, Lemey P, Baele G. Temporal signal and the phylodynamic threshold of SARS-CoV-2. Virus Evol. 2020;6.

4. van Dorp L, Acman M, Richard D, Shaw LP, Ford CE, Ormond L, et al. Emergence of genomic diversity and recurrent mutations in SARS-CoV-2. Infect Genet Evol. 2020; 83. https://pubmed.ncbi.nlm.nih.gov/32387564/

5. van Dorp L, Richard D, Tan CCS, Shaw LP, Acman M, Balloux F. No evidence for increased transmissibility from recurrent mutations in SARSCoV-2. Nat Commun. 2020. https://pubmed.ncbi.nlm.nih.gov/33239633/

6. Giovanetti M, Benvenuto D, Angeletti S, Ciccozzi M. The first two cases of 2019-nCoV in Italy: Where they come from? J Med Virol. 2020;92:518-21.

7. Li X, Wang W, Zhao X, Zai J, Zhao Q, Li Y, et al. Transmission dynamics and evolutionary history of 2019-nCoV. J Med Virol. 2020;92:501-11.

8. Wu F, Zhao S, Yu B, Chen YM, Wang W, Song ZG, et al. A new coronavirus associated with human respiratory disease in China. Nature. 2020;579:265-9.

9. GISAID - hCov19 Variants [Internet]. [cited 2021 Jun 6]. https://www. gisaid.org/hcov19-variants/

10. Yan R, Zhang Y, Li Y, Xia L, Guo Y, Zhou Q. Structural basis for the recognition of SARS-CoV-2 by full-length human ACE2. Science. 2020; 367:1444-8.

11. Li W, Moore MJ, Vasilieva N, Sui J, Wong SK, Berne MA, et al. Angiotensinconverting enzyme 2 is a functional receptor for the SARS coronavirus. Nature. 2003:426:450-4.

12. Li F, Li W, Farzan M, Harrison SC. Structure of SARS coronavirus spike receptor-binding domain complexed with receptor. Science United States. 2005;309:1864-8.

13. Huang Y, Yang C, Xu X, Feng, Xu W, Liu S wen. Structural and functional properties of SARS-CoV-2 spike protein: potential antivirus drug development for COVID-19. Acta Pharmacol Sin. 2020. https://doi.org/10.1038/ s41401-020-0485-4

14. Yi C, Sun $X$, Ye J, Ding L, Liu M, Yang Z, et al. Key residues of the receptor binding motif in the spike protein of SARS-CoV-2 that interact with ACE2 and neutralizing antibodies. Cell Mol Immunol. 2020;17:621-30. https:// doi.org/10.1038/s41423-020-0458-z.

15. Lan J, Ge J, Yu J, Shan S, Zhou H, Fan S, et al. Structure of the SARS-CoV-2 spike receptor-binding domain bound to the ACE2 receptor. Nature. 2020;581:215-20. https://doi.org/10.1038/s41586-020-2180-5.

16. Shang J, Ye G, Shi K, Wan Y, Luo C, Aihara H, et al. Structural basis of receptor recognition by SARS-CoV-2. Nature. 2020;581:221-4.

17. Piccoli L, Park YJ, Tortorici MA, Czudnochowski N, Walls AC, Beltramello $M$, et al. Mapping neutralizing and immunodominant sites on the SARSCoV-2 spike receptor-binding domain by structure-guided high-resolution serology. Cell. 2020;183:1024-1042.e21.

18. Investigation of novel SARS-COV-2 variant: Variant of Concern 202012/01 - GOV.UK [Internet]. gov.uk. 2020. https://www.gov.uk/government/publi cations/nervtag-paper-on-covid-19-variant-of-concern-

19. Fratev F. The SARS-CoV-2 S1 spike protein mutation N501Y alters the protein interactions with both hACE2 and human derived antibody: a Free energy of perturbation study [Internet]. bioRxiv. bioRxiv; 2020 [cited 2021 Feb 20]. p. 2020.12.23.424283. https://doi.org/10.1101/2020.12.23.424283

20. Edara W, Norwood C, Floyd K, Lai L, Davis-Gardner ME, Hudson WH, et al. Reduced binding and neutralization of infection- and vaccineinduced antibodies to the B.1.351 (South African) SARS-CoV-2 variant.
bioRxiv Prepr Serv Biol [Internet]. 2021. http://www.ncbi.nlm.nih.gov/ pubmed/33655254\%0Ahttp://www.pubmedcentral.nih.gov/articlerender.fcgi?artid=PMC7924283

21. Starr TN, Greaney AJ, Addetia A, Hannon WW, Choudhary MC, Dingens AS, et al. Prospective mapping of viral mutations that escape antibodies used to treat COVID-19. Science (80- ) [Internet]. 2021 [cited 2021 Feb 7]:eabf9302. https://doi.org/10.1126/science.abf9302

22. Nelson G, Buzko O, Patricia S, Niazi K, Rabizadeh S, Soon-Shiong P. Molecular dynamic simulation reveals E484K mutation enhances spike RBD-ACE2 affinity and the 1 combination of E484K, K417N and N501Y mutations (501Y.V2 variant) induces conformational 2 change greater than N501Y mutant alone, potentially resulting in an e. bioRxiv [Internet]. 2021 [cited 2021 Feb 7];2021.01.13.426558. https://doi.org/10.1101/2021. 01.13 .426558

23. Starr TN, Greaney AJ, Hilton SK, Ellis D, Crawford KHD, Dingens AS, et al. Deep mutational scanning of SARS-CoV-2 receptor binding domain reveals constraints on folding and ACE2 binding. Cell. 2020;182:12951310.e20.

24. Plante JA, Liu Y, Liu J, Xia H, Johnson BA, Lokugamage KG, et al. Spike mutation D614G alters SARS-CoV-2 fitness. Nature. 2021;592:116-21. https://doi.org/10.1038/s41586-020-2895-3.

25. Zhang L, Jackson CB, Mou H, Ojha A, Peng H, Quinlan BD, et al. SARSCoV-2 spike-protein D614G mutation increases virion spike density and infectivity. Nat Commun. 2020;11.

26. Hou YJ, Chiba S, Halfmann P, Ehre C, Kuroda M, Dinnon KH, et al. SARSCoV-2 D614G variant exhibits efficient replication ex vivo and transmission in vivo. Science. 370:1464-8

27. McCarthy KR, Rennick LJ, Nambulli S, Robinson-McCarthy LR, Bain WG, Haidar G, et al. Recurrent deletions in the SARS-CoV-2 spike glycoprotein drive antibody escape. Science. 2021;eabf6950. http://science.scien cemag.org/content/early/2021/02/02/science.abf6950.abstract

28. Xia H, Cao Z, Xie X, Zhang X, Chen JYC, Wang H, et al. Evasion of Type I Interferon by SARS-CoV-2. Cell Rep. 2020;33: 108234. https://doi.org/10. 1016/j.celrep.2020.108234.

29. Lin J, Tang C, Wei H, Du B, Chen C, Wang M, et al. Genomic monitoring of SARS-CoV-2 uncovers an Nsp1 deletion variant that modulates type I interferon response. Cell Host Microbe; 2021.

30. Flower TG, Buffalo CZ, Hooy RM, Allaire M, Ren X, Hurley JH. Structure of SARS-cov-2 ORF8, a rapidly evolving immune evasion protein. Proc Natl Acad Sci U S A. 2021;118:1-6.

31. Young BE, Fong SW, Chan YH, Mak TM, Ang LW, Anderson DE, et al. Effects of a major deletion in the SARS-CoV-2 genome on the severity of infection and the inflammatory response: an observational cohort study. Lancet. 2020;396:603-11.

32. Rambaut A, Loman N, Pybus O, Barclay W, Barrett J, Carabelli A, et al. Preliminary genomic characterisation of an emergent SARS-CoV-2 lineage in the UK defined by a novel set of spike mutations - SARS-CoV-2 coronavirus/nCoV-2019 Genomic Epidemiology - Virological. Virological. org [Internet]. 2020 [cited 2021 May 31];1-9. https://virological.org/t/preli minary-genomic-characterisation-of-an-emergent-sars-cov-2-lineage-inthe-uk-defined-by-a-novel-set-of-spike-mutations/563

33. Butowt R, Bilinska K, Von Bartheld CS. Chemosensory dysfunction in COVID-19: integration of genetic and epidemiological data points to D614G spike protein variant as a contributing factor. ACS Chem Neurosci. 2020;11:3180-4.

34. Zhou B, Thao TTN, Hoffmann D, Taddeo A, Ebert N, Labroussaa F, et al. SARS-CoV-2 spike D614G change enhances replication and transmission. Nature; 2021. http://www.nature.com/articles/s41586-021-03361-1

35. Grubaugh ND, Hanage WP, Rasmussen AL. Making sense of mutation: what D614G means for the COVID-19 pandemic remains unclear. Cell. 2020;182:794-5.

36. Korber B, Fischer WM, Gnanakaran S, Yoon H, Theiler J, Abfalterer W, et al. Tracking changes in SARS-CoV-2 spike: evidence that D614G increases infectivity of the COVID-19 virus. Cell. 2020;182:812-827.e19.

37. Volz E, Hill V, McCrone JT, Price A, Jorgensen D, O'Toole Á, et al. Evaluating the effects of SARS-CoV-2 spike mutation D614G on transmissibility and pathogenicity. Cell Cell Press. 2021;184:64-75.e11.

38. Mlcochova P, Collier D, Ritchie A, Assennato SM, Hosmillo M, Goel N, et al. Combined Point-of-Care Nucleic Acid and Antibody Testing for SARSCoV-2 following Emergence of D614G Spike Variant. Cell Reports Med; 2020. https://pubmed.ncbi.nlm.nih.gov/32905045/ 
39. Washington NL, Gangavarapu K, Zeller M, Bolze A, Cirulli ET, Schiabor Barrett KM, et al. Genomic epidemiology identifies emergence and rapid transmission of SARS-CoV-2 B.1.1.7 in the United States. medRxiv [Internet]. medRxiv; 2021;2021.02.06.21251159. http://www.ncbi.nlm.nih.gov/ pubmed/33564780

40. Volz E, Mishra S, Chand M, Barrett JC, Johnson R, Geidelberg L, et al. Assessing transmissibility of SARS-CoV-2 lineage B.1.1.7 in England. Nature 2021. https://doi.org/10.1038/s41586-021-03470-X

41. Wang P, Liu L, Iketani S, Luo Y, Guo Y, Wang M, et al. Increased Resistance of SARS-CoV-2 Variants B.1.351 and B.1.1.7 to Antibody Neutralization. bioRxiv Prepr Serv Biol [Internet]. Cold Spring Harbor Laboratory; 2021 [cited 2021 Mar 15];2021.01.25.428137. http://www.ncbi.nlm.nih.gov/ pubmed/33532778

42. Deng X, Garcia-knight MA, Khalid MM, Servellita V, Morris MK, Sotomayorgonzález A, et al. Transmission, infectivity, and neutralization of a spike L452R SARS-CoV-2 variant. Cell. 2021. https://doi.org/10.1016/j.cell.2021. 04.025 .

43. Zhang W, Davis BD, Chen SS, Sincuir Martinez JM, Plummer JT, Vail E. Emergence of a novel SARS-CoV-2 variant in Southern California. JAMA Am Med Assoc. 2021; 1324-6. https://pubmed.ncbi.nlm.nih.gov/33571 356/

44. Yang JR, Kuo CY, Huang HY, Wu FT, Huang YL, Cheng CY, et al. Newly emerging mutations in the matrix genes of the human influenza a(h1n1) pdm09 and a(h3n2) viruses reduce the detection sensitivity of real-time reverse transcription-pcr. J Clin Microbiol. 2014;52:76-82.

45. Shu Y, McCauley J. GISAID: Global initiative on sharing all influenza data - from vision to reality [Internet]. Eurosurveillance. European Centre for Disease Prevention and Control (ECDC); 2017. https://pubmed.ncbi.nlm. nih.gov/28382917/

46. Jain A, Rophina M, Mahajan S, Krishnan BB, Sharma M, Mandal S, et al. Analysis of the potential impact of genomic variants in global SARS-CoV-2 genomes on molecular diagnostic assays. Int J Infect Dis. 2021;102:460-2.

47. Ramírez JD, Muñoz M, Patiño LH, Ballesteros N, Paniz-Mondolfi A. Will the emergent SARS-CoV2 B.1.1.7 lineage affect molecular diagnosis of COVID-19? J Med Virol; 2021. https://pubmed.ncbi.nlm.nih.gov/33506 970/

48. Bal A, Destras G, Gaymard A, Stefic K, Marlet J, Eymieux S, et al. Twostep strategy for the identification of SARS-CoV-2 variant of concern 202012/01 and other variants with spike deletion H69-V70, France, August to December 2020. Euro Surveill; 2021 [cited 2021 Feb 27];26. https://pubmed.ncbi.nlm.nih.gov/33478625/

49. Pereira F. Evolutionary dynamics of the SARS-CoV-2 ORF8 accessory gene. Infect Genet Evol; 2020;85. https://pubmed.ncbi.nlm.nih.gov/32890763/

50. Gong YN, Tsao KC, Hsiao MJ, Huang CG, Huang PN, Huang PW, et al. SARSCoV-2 genomic surveillance in Taiwan revealed novel ORF8-deletion mutant and clade possibly associated with infections in Middle East. Emerg Microbes Infect. 2020;9:1457-66. https://clinicaltrials.gov/ct2/ show/NCT04684446

51. Hernández-Huerta MT, Pérez-Campos Mayoral L, Romero Díaz C, Martínez Cruz M, Mayoral-Andrade G, Sánchez Navarro LM, et al. Analysis of SARSCoV-2 mutations in Mexico, Belize, and isolated regions of Guatemala and its implication in the diagnosis. J Med Virol; 2020; 93. https://pubmed. ncbi.nlm.nih.gov/33049069/

52. Khan KA, Cheung P. Presence of mismatches between diagnostic PCR assays and coronavirus SARS-CoV-2 genome. R Soc Open Sci;7:200636

53. Gand M, Vanneste K, Thomas I, Van Gucht S, Capron A, Herman P, et al. Use of whole genome sequencing data for a first in silico specificity evaluation of the RT-QPCR assays used for SARS-CoV-2 detection. Int J Mol Sci. 2020;21:1-25.

54. Arena F, Pollini S, Rossolini GM, Margaglione M. Summary of the available molecular methods for detection of SARS-CoV-2 during the ongoing pandemic. Int J. Mol. Sci. 2021. p. 1-14. https://pubmed.ncbi.nlm.nih.gov/ 33525651/

55. Vogels CBF, Brito AF, Wyllie AL, Fauver JR, Ott IM, Kalinich CC, et al. Analytical sensitivity and efficiency comparisons of SARS-CoV-2 RT-qPCR primer-probe sets. Nat Microbiol. 2020;5:1299-305.

56. Kuchinski KS, Jassem AN, Prystajecky NA. Assessing oligonucleotide designs from early lab developed PCR diagnostic tests for SARS-CoV-2 using the PCR_strainer pipeline. J Clin Virol; 2020;131. https://pubmed. ncbi.nlm.nih.gov/32889496/
57. Wang Y, Zhang Y, Chen J, Wang M, Zhang T, Luo W, et al. Detection of SARS-CoV-2 and its mutated variants via CRISPR-Cas13-based transcription amplification. Anal Chem; 2021. https://doi.org/10.1021/acs.analc hem.0c04303

58. Liu Y, Liu J, Xia H, Zhang X, Fontes-Garfias CR, Swanson KA, et al. Neutralizing Activity of BNT162b2-Elicited Serum - Preliminary Report. N Engl J. 2021; NEJMc2102017. http://www.ncbi.nlm.nih.gov/pubmed/33596352

59. Muik A, Wallisch A-K, Sänger B, Swanson KA, Mühl J, Chen W, et al. Neutralization of SARS-CoV-2 lineage B.1.1.7 pseudovirus by BNT162b2 vaccine-elicited human sera. Science (80- ) 2021;371:eabg6105. https:// doi.org/10.1101/2020.12.30.20249034.

60. Wu K, Werner AP, Koch M, Choi A, Narayanan E, Stewart-Jones GBE, et al. Serum neutralizing activity elicited by mRNA-1273 vaccine- preliminary report. N Engl J Med 2021;NEJMc2102179. https://doi.org/10.1056/ NEJMC2102179

61. Wu K, Werner AP, Moliva Jl, Koch M, Choi A, Steward-Jones GBE, et al. mRNA-1273 vaccine induces neutralizing antibodies against spike mutants from global SARS-CoV-2 variants. bioRxiv. 2021;

62. Vaccines and Related Biological Products Advisory Committee February 26, 2021 Meeting Announcement - 02/26/2021 - 02/26/2021 |FDA. https://www.fda.gov/advisory-committees/advisory-committee-calen dar/vaccines-and-related-biological-products-advisory-committee-febru ary-26-2021-meeting-announcement\#event-materials

63. Emary KRW, Golubchik T, Aley PK, Ariani C V., Angus BJ, Bibi S, et al. Efficacy of ChAdOx1 nCoV-19 (AZD1222) Vaccine Against SARS-CoV-2 VOC 202012/01 (B.1.1.7). Lancet Prepr. 2021;

64. Madhi SA, Baillie V, Cutland CL, Voysey M, Koen AL, Fairlie L, et al. Efficacy of the ChAdOx1 nCoV-19 Covid-19 Vaccine against the B.1.351 Variant. N Engl J Med; 2021; https://doi.org/10.1056/NEJMoa2102214

65. Russian scientists say Sputnik V performs well against COVID mutations | Reuters. https://www.reuters.com/article/us-health-coronavirus-sputn ik-mutations-idUSKBN2AROE7

66. AstraZeneca Vax - Sputnik V Combination Study - Full Text View - ClinicalTrials.gov. https://clinicaltrials.gov/ct2/show/NCT 04684446

67. Novavax Confirms High Levels of Efficacy Against Original and Variant COVID-19 Strains in United Kingdom and South Africa Trials [Internet]. 2021. https://www.novavax.com/resources\#protocols

68. Huang B, Dai L, Wang H, Hu Z, Yang X, Tan W, et al. Neutralization of SARSCoV-2 VOC 501Y.V2 by human antisera elicited by both 1 inactivated BBIBP-CorV and recombinant dimeric RBD ZF2001 vaccines 23 Authors. bioRxiv [Internet]. Cold Spring Harbor Laboratory; 2021 [cited 2021 Mar 17];2021.02.01.429069. https://doi.org/10.1101/2021.02.01.429069

69. Sapkal GN, Yadav PD, Ella R, Deshpande GR, Sahay RR, Gupta N, et al. Neutralization of UK-variant VUI-202012/01 with COVAXIN vaccinated human serum. bioRxiv [Internet]. 2021 [cited 2021 Mar 17]; https://doi.org/10. $1101 / 2021.01 .26 .426986$

70. Preliminary data indicates Sinovac COVID-19 vaccine effective against Brazilian P1 variant: official | Reuters [Internet]. [cited 2021 Mar 17]. https://www.reuters.com/article/us-health-coronavirus-brazil-variantidUSKBN2B2274

71. Sinovac vaccine works on UK, South African variants - Brazil institute | Reuters [Internet]. [cited 2021 Mar 17]. https://www.reuters.com/article/ us-health-coronavirus-brazil-idUSKBN2AH2HO

72. Moderna COVID-19 Vaccine Retains Neutralizing Activity Against Emerging Variants First Identified in the U.K. and the Republic of South Africa. 2021.

73. Ye G, Gallant JP, Massey C, Shi K, Tai W, Zheng J, et al. The Development of a Novel Nanobody Therapeutic for SARS-CoV-2 [Internet]. bioRxiv. bioRxiv; 2020 [cited 2021 Mar 28]. p. 2020.11.17.386532. https://doi.org/ $10.1101 / 2020.11 .17 .386532$

74. Grand R Le, Maisonnasse P, Aldon Y, Marc A, Marlin R, Dereuddre-Bosquet $\mathrm{N}$, et al. COVA1-18 neutralizing antibody protects against SARS-CoV-2 in three preclinical models. Res Sq [Internet]. Res Sq; 2021 [cited 2021 Mar 28]; http://www.ncbi.nlm.nih.gov/pubmed/33619476

75. Ramanathan M, Ferguson ID, Miao W, Khavari PA. SARS-CoV-2 B.1.1.7 and B.1.351 Spike variants bind human ACE2 with increased affinity. bioRxiv Prepr Serv Biol [Internet]. Cold Spring Harbor Laboratory; 2021 [cited 2021 Mar 28];2021.02.22.432359. http://www.ncbi.nlm.nih.gov/pubmed/ 33655251

76. De Gasparo R, Pedotti M, Simonelli L, Nickl P, Muecksch F, Percivalle $\mathrm{E}$, et al. Bispecific antibody neutralizes circulating SARS-CoV-2 
variants, prevents escape and protects mice from disease 23. bioRxiv [Internet]. Cold Spring Harbor Laboratory; 2021 [cited 2021 Mar 28];2021.01.22.427567. https://doi.org/10.1101/2021.01.22.427567

77. Reuschl A-K, Thorne L, Zuliani Alvarez L, Bouhaddou M, Obernier K, Soucheray $M$, et al. Host-directed therapies against early-lineage SARSCoV-2 retain efficacy against B.1.1.7 variant. bioRxiv Prepr Serv Biol 2021;10:9.

78. Bessalah S, Jebahi S, Mejri N, Salhi I, Khorchani T, Hammadi M. Perspective on therapeutic and diagnostic potential of camel nanobodies for coronavirus disease-19 (COVID-19). 3 Biotech; 2021. https://doi.org/10. 1007/s13205-021-02647-5

79. Wysocki J, Ye M, Hassler L, Gupta AK, Wang Y, Nicoleascu V, et al. A Novel Soluble ACE2 Variant with Prolonged Duration of Action Neutralizes SARS-CoV-2 Infection in Human Kidney Organoids. J Am Soc Nephrol. 2021;ASN.2020101537. www.jasn.org

80. Wysocki J, Ye M, Soler MJ, Gurley SB, Xiao HD, Bernstein KE, et al. ACE and ACE2 activity in diabetic mice. Diabetes. 2006;55:2132-9.

81. Higuchi Y, Suzuki T, Arimori T, Ikemura N, Kirita Y, Ohgitani E, et al. High affinity modified ACE2 receptors prevent SARS-CoV-2 infection [Internet]. bioRxiv. bioRxiv; 2020 [cited 2021 Mar 28]. p. 2020.09.16.299891. https:// doi.org/10.1101/2020.09.16.299891

82. Chan KK, Dorosky D, Sharma P, Abbasi SA, Dye JM, Kranz DM, et al. Engineering human ACE2 to optimize binding to the spike protein of SARS coronavirus 2. Science (80-) $2020 ; 369: 1261-5$

83. Twomey JD, Luo S, Dean AQ, Bozza WP, Nalli A, Zhang B. COVID-19 update: The race to therapeutic development. Drug Resist. Updat. Churchill Livingstone; 2020. p. 100733.

84. Shang C, Zhuang X, Zhang H, Li Y, Zhu Y, Lu J, et al. Inhibitors of endosomal acidification suppress SARS-CoV-2 replication and relieve viral pneumonia in hACE2 transgenic mice. Virol J. 2021;18:46.

85. Deng Q, Rasool R ur, Russell RM, Natesan R, Asangani IA. Targeting androgen regulation of TMPRSS2 and ACE2 as a therapeutic strategy to combat COVID-19. iscience 2021;24:102254.
86. Haga S, Nagata N, Okamura T, Yamamoto N, Sata T, Yamamoto N, et al. TACE antagonists blocking ACE2 shedding caused by the spike protein of SARS-CoV are candidate antiviral compounds. Antiviral Res. 2010;85:5515. https://doi.org/10.1016/j.antiviral.2009.12.001.

87. Agostini ML, Andres EL, Sims AC, Graham RL, Sheahan TP, Lu X, et al. Coronavirus susceptibility to the antiviral remdesivir (GS-5734) is mediated by the viral polymerase and the proofreading exoribonuclease. MBio. 2018:9:221-39.

88. Heydari H, Golmohammadi R, Mirnejad R, Tebyanian H, Fasihi-Ramandi M, Moosazadeh-Moghadam M. Antiviral peptides against Coronaviridae family: A review. Peptides;139:170526

89. Pachetti M, Marini B, Benedetti F, Giudici F, Mauro E, Storici P, et al. Emerging SARS-CoV-2 mutation hot spots include a novel RNA-dependentRNA polymerase variant. J Transl Med. 18:179. https://doi.org/10.1186/ s12967-020-02344-6

90. Goldhill DH, Te Velthuis AJW, Fletcher RA, Langat P, Zambon M, Lackenby A, et al. The mechanism of resistance to favipiravir in influenza. Proc Natl Acad Sci U S A. 2018;115:11613-8. https://doi.org/10.1073/pnas.18113 45115.

91. Young KC, Lindsay KL, Lee KJ, Liu WC, He JW, Milstein SL, et al. Identification of a ribavirin-resistant NS5B mutation of hepatitis C virus during ribavirin monotherapy. Hepatology. 2003;38:869-78.

92. Abbott TR, Dhamdhere G, Liu Y, Lin X, Goudy L, Zeng L, et al. Development of CRISPR as an Antiviral Strategy to Combat SARS-CoV-2 and Influenza. Cell. 2020;181:865-876.e12. https://doi.org/10.1016/j.cell.2020. 04.020.

\section{Publisher's Note}

Springer Nature remains neutral with regard to jurisdictional claims in published maps and institutional affiliations.
Ready to submit your research? Choose BMC and benefit from:

- fast, convenient online submission

- thorough peer review by experienced researchers in your field

- rapid publication on acceptance

- support for research data, including large and complex data types

- gold Open Access which fosters wider collaboration and increased citations

- maximum visibility for your research: over 100M website views per year

At BMC, research is always in progress.

Learn more biomedcentral.com/submissions 